\title{
Dlaczego warto stosować walsartan i jego skojarzenia u pacjentów z nadciśnieniem tętniczym?
}

\author{
Why to use valsartan and its combinations in patients with hypertension?
}

\section{Agata Tymińska, Agnieszka Kapłon-Cieślicka}

I Katedra i Klinika Kardiologii Warszawskiego Uniwersytetu Medycznego

\section{STRESZCZENIE}

W najnowszych wytycznych dotyczących leczenia nadciśnienia tętniczego określono docelowe wartości ciśnienia na poniżej 130/80 mm Hg u większości pacjentów z zaleceniem, aby terapia hipotensyjna rozpoczynała się od preparatu złożonego (SPC) dwuskładnikowego. Oprócz silnego działania hipotensyjnego stosowanie walsartanu wiąże się z obniżeniem ryzyka metabolicznego oraz zmniejszeniem częstości występowania powikłań narządowych i zdarzeń sercowo-naczyniowych. Walsartan jest jedynym sartanem preferowanym zarówno u pacjentów z nadciśnieniem tętniczym i współistniejącą chorobą wieńcową, jak i u chorych z niewydolnością serca. Zastosowanie skojarzenia walsartanu z amlodipiną lub hydrochlorotiazydem wiąże się z jednej strony z udowodnionym, silniejszym efektem hipotensyjnym, wynikającym z synergistycznego działania obu molekuł, a z drugiej strony z ograniczeniem częstości działań niepożądanych (takich jak obrzęki obwodowe w przypadku monoterapii amlodipiną czy hipokaliemia w przypadku monoterapii hydrochlorotiazydem).

Choroby Serca i Naczyń 2019, 16 (3), 172-183

Słowa kluczowe: amlodipina, choroby układu sercowo-naczyniowego, hydrochlorotiazyd, nadciśnienie tętnicze, terapia złożona, walsartan

\section{ABSTRACT}

The most recent guidelines for the treatment of arterial hypertension have set blood pressure targets of below $130 / 80 \mathrm{~mm} \mathrm{Hg}$ in most patients, recommending a single-pill combination (SPC) consisting of two drugs for treatment initiation. In addition to its strong antihypertensive effect, the use of valsartan is associated with a reduction in metabolic risk and in the incidence of hypertension-mediated organ damage and cardiovascular events. Valsartan is the only angiotensin receptor blocker of choice both in patients with hypertension and concomitant coronary artery disease, and in patients with heart failure. The combination of valsartan with

Adres do korespondencji:

dr hab. n. med. Agnieszka Kapłon-Cieślicka

I Katedra i Klinika Kardiologii

Uniwersyteckie Centrum Kliniczne

Warszawski Uniwersytet Medyczny

ul. Banacha 1a, 02-097 Warszawa

tel. +4822 5992958 , faks +48225991957

e-mail: agnieszka.kaplon-cieslicka@wum.edu.pl 
amlodipine or hydrochlorothiazide is associated with a proven stronger hypotensive effect due to the synergistic effect of both molecules on the one hand, and a reduction in the frequency of side effects (such as peripheral oedema with amlodipine monotherapy or hypokalemia with hydrochlorothiazide monotherapy) on the other. Choroby Serca i Naczyń 2019, 16 (3), 172-183

Key words: amlodipine, arterial hypertension, cardiovascular diseases, hydrochlorothiazide, single-pill combination, valsartan

\section{WPROWADZENIE}

Według Światowej Organizacji Zdrowia (WHO, World Health Organization) choroby układu krążenia są najczęstszą przyczyną zgonów na świecie, prowadząc do około 18 milionów zgonów rocznie, co stanowi około $31 \%$ wszystkich zgonów na świecie [1]. Kluczową rolę w prewencji chorób układu sercowo-naczyniowego odgrywa modyfikacja czynników ryzyka. Nadciśnienie tętnicze pozostaje jednym z najsilniejszych i najbardziej rozpowszechnionych spośród modyfikowalnych czynników ryzyka sercowo-naczyniowego [2,3]. Zgodnie z danymi z dużych badań NATPOL 2011 i WOBASZ wciąż obserwuje się zwiększenie zapadalności na nadciśnienie tętnicze w Polsce [4, 5]. Na podstawie badania NATPOL 2011 rozpowszechnienie nadciśnienia tętniczego wśród osób w wieku 18-79 lat można oszacować na blisko 10 milionów osób [5]. Utrzymywanie się obserwowanej tendencji może spowodować nawet 2-krotny wzrost liczby pacjentów z nadciśnieniem tętniczym do roku 2035 [2]. Powikłania nadciśnienia tętniczego odpowiadają za blisko połowę przedwczesnych zgonów na świecie. Skuteczna kontrola ciśnienia tętniczego (BP, blood pressure) istotnie obniża względne ryzyko zgonu (o 10-15\%) oraz ryzyko incydentów sercowo-naczyniowych (zawał serca, udar mózgu, choroby tętnic obwodowych, niewydolność serca [HF, heart failure] — o ok. 20\%), jak również ryzyko rozwoju niewydolności nerek $[2,6]$. W ubiegłym roku zostały ogłoszone wytyczne towarzystw europejskich (ESC/ESH, European Society of Cardiology/European Society of Hypertension) dotyczące postępowania w nadciśnieniu tętniczym, a w bieżącym roku opublikowano długo wyczekiwane zalecenia Polskiego Towarzystwa Nadciśnienia Tętniczego (PTNT) [2,3].

\section{CELE LECZENIA NADCIŚNIENIA TĘTNICZEGO — CZY TYLKO OBNIŻENIE WARTOŚCI CIŚNIENIA?}

Celem terapii nadciśnienia tętniczego jest obniżenie ryzyka powikłań sercowo-naczyniowych [2]. Stwierdze- nie to ma dwie ważne konsekwencje. Po pierwsze, we wstępnej ocenie pacjenta z podwyższonymi wartościami BP powinno się uwzględniać oszacowanie całkowitego ryzyka sercowo-naczyniowego $[7,8]$. W przypadku osób z nadciśnieniem tętniczym 1 . stopnia i cechujących się ryzykiem niskim bądź umiarkowanym moment rozpoczęcia farmakoterapii hipotensyjnej można odroczyć o 3-6 miesięcy, wdrażając początkowo modyfikację stylu życia [2]. Z kolei w przypadku pacjentów obciążonych bardzo wysokim ryzykiem sercowo-naczyniowym włączenie leku hipotensyjnego należy rozważyć już w przypadku ciśnienia wysokiego prawidłowego [2]. Po drugie, przy wyborze leku hipotensyjnego należy się kierować nie tylko samym stopniem spodziewanego obniżenia wartości BP, ale także udowodnionymi w badaniach randomizowanych $\mathrm{w}$ danej populacji chorych korzyściami klinicznymi w postaci zmniejszenia ryzyka zdarzeń sercowo-naczyniowych. Oznacza to, że wybór leku przeciwnadciśnieniowego powinien być dostosowany do profilu klinicznego pacjenta, z uwzględnieniem zarówno wyjściowych wartości BP, jak i chorób towarzyszących, istniejących przeciwwskazań do stosowania danego leku oraz potencjalnych działań niepożądanych leku. W przypadku stosowania terapii skojarzonej, niezbędnej u większości pacjentów z nadciśnieniem tętniczym, należy preferować połączenia o skuteczności potwierdzonej w badaniach klinicznych.

\section{DOCELOWE WARTOŚCI CIŚNIENIA TĘTNICZEGO — NIŻSZE NIŻ POPRZEDNIO}

Według europejskich wytycznych ESC/ESH 2018 oraz zaleceń PTNT 2019 docelowa wartość ciśnienia skurczowego (SBP, systolic blood pressure) wynosi poniżej $140 \mathrm{~mm} \mathrm{Hg}$, niezależnie od poziomu ryzyka sercowo-naczyniowego $[2,3]$. Przy dobrej tolerancjileczenia hipotensyjnego u chorych poniżej 65. roku życia zaleca się dalsze obniżanie wartości SBP poniżej $130 \mathrm{~mm} \mathrm{Hg}$ (ale nie $\leq 120 \mathrm{~mm} \mathrm{Hg}$ ) $[2,3,9]$. Natomiast w przypadku ciśnienia rozkurczowego (DBP, diastolic blood pressure) należy dążyć do osiągnięcia 
wartości poniżej $80 \mathrm{~mm} \mathrm{Hg}$ (wg PTNT 2019 nie $\leq 70 \mathrm{~mm} \mathrm{Hg}$, z wyjątkiem pacjentów z izolowanym nadciśnieniem skurczowym, u których dopuszcza się obniżenie DBP do $65 \mathrm{~mm} \mathrm{Hg}$ ) [2,3]. Ta rewolucja w docelowych wartościach BP jest pokłosiem wyników badania SPRINT (The Systolic blood PRessure INtemention Trial), w którym bardziej intensywna kontrola BP wiązała się z obniżeniem ryzyka zgonu i powikłań sercowo-naczyniowych o około 30\% [10].

\section{MIEJSCE SARTANÓW}

\section{W TERAPII NADCIŚNIENIA TETTICZEGO}

W aktualnych wytycznych PTNT z 2019 roku utrzymano pięć podstawowych grup leków hipotensyjnych, w odniesieniu do których udowodniono zmniejszenie śmiertelności i ryzyka incydentów sercowo-naczyniowych $\mathrm{w}$ różnych subpopulacjach pacjentów z nadciśnieniem tętniczym: inhibitory konwertazy angiotensyny (ACE, angiotensin-converting enzyme), antagonistów receptora $\mathrm{AT}_{1}$ dla angiotensyny II zwanych potocznie sartanami (ARB, angiotensin receptor blockers), antagonistów wapnia, diuretyki i beta-adrenolityki [2]. Na tle pozostałych czterech grup leków hipotensyjnych ARB wyróżniają się najlepszym profilem tolerancji (zbliżonym do placebo), przy zachowanej wysokiej skuteczności w obniżaniu wartości BP. Niska częstość działań niepożądanych w przypadku ARB wiąże się z rzadszym ich odstawianiem przez pacjentów — odsetek osób kontynuujących terapię ARB jest najwyższy w porównaniu z innymi lekami hipotensyjnymi $[2,11]$. Podobnie jak inhibitory ACE, ARB wykazują właściwości kardio- i renoprotekcyjne oraz korzystny profil metaboliczny, a tym samym mogą byćlekami pierwszego wyboru u pacjentów z nadciśnieniem tętniczym i wspólistniejącymi uszkodzeniami narządowymi (np. przerostem lewej komory serca, nefropatią nadciśnieniową), zespołem metabolicznym, cukrzycą czy przewlekłą chorobą nerek (w tym nefropatią cukrzycową). U pacjentów z HF lub chorobą wieńcową, ze względu na niższe ryzyko działań niepożądanych, ARB są alternatywą dla inhibitorów ACE w przypadku ich nietolerancji. Ponadto ARB preferuje się w stosunku do inhibitorów ACE u pacjentów z nadciśnieniem tętniczym po przebytym udarze mózgu lub ze wspólistniejącą chorobą płuc (astmą bądź przewlekłą obturacyjną chorobą płuc) [2].

\section{PLEJOTROPOWE DZIALANIA SARTANÓW}

Wielokierunkowe, korzystne efekty stosowania ARB wiążą się przede wszystkim (ale nie tylko) z hamowaniem przez te leki układu renina-angiotensyna-aldoste- ron (RAA). W działaniu angiotensyny II pośredniczą dwa receptory - typu 1 i $2\left(\mathrm{AT}_{1} \mathrm{i}_{\mathrm{AT}}\right)$. Stymulacja receptora $\mathrm{AT}_{1}$ powoduje wazokonstrykcję oraz zwiększone wydzielanie aldosteronu, wazopresyny i endoteliny, które dalej podwyższają BP. Selektywnie blokując receptory $\mathrm{AT}_{1}$, sartany hamują niepożądane działania angiotensyny II na poziomie różnych tkanek: układu tętniczego, serca, nerek, nadnerczy i ośrodkowego układu nerwowego. Zablokowanie receptora $\mathrm{AT}_{1}$ przez $\mathrm{ARB}$ ogranicza bezpośrednie kurczące działanie angiotensyny II na mięśnie gładkie naczyń tętniczych, zmniejsza opór obwodowy i obciążenie następcze oraz zwiększa pojemność minutową serca, nie powodując odruchowej tachykardii. Zmniejszając wydzielanie aldosteronu, ARB hamują retencję sodu i wody (zmniejszenie obciążenia wstępnego). Poprzez działanie rozszerzające, zwłaszcza na tętniczki odprowadzające, obniżają ciśnienie hydrostatyczne w kłębuszkach nerkowych i hiperfiltrację kłębuszkową, która jest ważnym czynnikiem uszkadzającym nerki. Sartany nie wykazują działania antagonistycznego w stosunku do receptorów $\mathrm{AT}_{2}$, natomiast zwiększone $\mathrm{w}$ wyniku ich działania stężenie angiotensyny II powoduje pobudzenie tych receptorów, prowadząc do dalszego, pośredniego działania wazodylatacyjnego (na drodze zwiększenia stężeń tlenku azotu i prostacykliny w ścianie naczyń krwionośnych), jak również do ograniczenia proliferacji komórek i zahamowania przerostu błony mięśniowej naczyń. Te pośrednie, "niehemodynamiczne" efekty działania ARB prowadzą do długotrwałych korzystnych zmian na poziomie serca, naczyń krwionośnych i nerek; leczenie ARB powoduje zahamowanie przerostu lewej komory serca, poprawę elastyczności dużych tętnic i zmniejszenie stosunku grubości mięśniówki do średnicy światła w małych tętnicach (efekty kardio- i wazoprotekcyjne), a także ograniczenie proliferacji komórek mezangialnych i gromadzenia macierzy międzykomórkowej w kłębuszkach nerkowych (efekt nefroprotekcyjny) [12-14].

\section{WALSARTAN NA TLE INNYCH LEKÓW Z TEJ GRUPY}

Sartany są niejednorodną grupą leków — różnią się pod względem struktury chemicznej, właściwości farmakokinetycznych i farmakodynamicznych [15-18]. Walsartan to przedstawiciel grupy sartanów wykazujący silne działanie hipotensyjne, ale mający również zastosowanie $\mathrm{w}$ wielu innych wskazaniach. Warto podkreślić, że zgodnie z pozycjonowaniem różnych ARB w wytycznych PTNT 2019 walsartan jest jedynym sartanem preferowanym zarówno u pacjentów z chorobą wieńcową (obok 
telmisartanu), jak i u chorych z HF z obniżoną frakcją wyrzutową (obok kandesartanu) [2]. Również w wytycznych ESC dotyczących postępowania w HF wymienia się walsartan w grupie leków o udowodnionym wpływie na chorobowość i śmiertelność w HF [19].

W 2018 roku zostały rozpowszechnione rekomendacje Europejskiej Agencji Leków (EMA, European Medicines Agency), a w ślad za nią — Głównego Inspektoratu Farmaceutycznego (GIF) w Polsce, dotyczące wstrzymania obrotu niektórymi produktami zawierającymi substancję czynną walsartan pochodzącą od chińskich wytwórców z powodu wykrycia zanieczyszczenia potencjalnie kancerogenną N-nitrozodimetyloaminą (NDMA, N-nitrosodimethylamine). Decyzją GIF część preparatów walsartanu została wycofana. Podczas weryfikacji procesów wytwórczych leku, przeprowadzonej następnie przez EMA i Europejski Dyrektoriat Jakości Leków i Ochrony Zdrowia (EDQM, European Directoratel /Department for the Quality of Medicines), nie stwierdzono żadnych zagrożeń w przypadku preparatów walsartanu pochodzących od innych wytwórców i dlatego preparaty te, jako bezpieczne, są ciągle dostępne do stosowania.

\section{WALSARTAN W NADCIŚNIENIU TĘTNICZYM}

Walsartan cechuje się prostą farmakokinetyką, szybko wchłania się z przewodu pokarmowego i nie ma czynnych metabolitów. U większości pacjentów działanie przeciwnadciśnieniowe rozpoczyna się w ciągu 2 godzin, a maksymalne obniżenie BP jest osiągane w czasie 4-6 godzin. W przypadku stosowania dawki $80 \mathrm{mg} 1 \mathrm{raz} /$ /dobę redukcja SBP wynosi średnio $11 \mathrm{~mm} \mathrm{Hg}$, a DBP - $8 \mathrm{~mm} \mathrm{Hg}$ po 4 tygodniach terapii [20]. Przeciwnadciśnieniowe działanie walsartanu utrzymuje się przez co najmniej 24 godziny od przyjęcia dawki, co, po pierwsze, pozwala na stosowanie leku raz dziennie (u pacjentów z nadciśnieniem tętniczym; w HF zaleca się podawanie $2 \times /$ d.), a przez to korzystnie wpływa na przestrzeganie zaleceń przez pacjenta (poprawa compliance), a, po drugie, umożliwia utrzymanie kontroli BP w nocy [18]. Jest to szczególnie istotne dla pacjentów typu non-dipper charakteryzujących się brakiem fizjologicznego spadku BP w nocy (lub spadkiem < 10\%), związanym ze zwiększoną częstością powikłań narządowych, w tym przerostu lewej komory serca, niekorzystnej przebudowy naczyń i niewydolności nerek. W tej grupie chorych wskazane może być zastosowanie preparatu hipotensyjnego w godzinach wieczornych (tzw. chronoterapia) — walsartan jest jednym z leków, w odniesieniu do których wykazano dużą skuteczność w odwracaniu profilu non-dipper w przypadku podania leku wieczorem [21, 22].

Walsartan nie jest metabolizowany przez cytochrom P450, dzięki czemu nie wchodzi w istotne klinicznie interakcje lekowe. Może być stosowany u osób w podeszłym wieku i pacjentów z przewlekłą chorobą nerek bez konieczności zmniejszania dawki leku [12, 13, 17].

U chorych na nadciśnienie tętnicze stosowanie walsartanu wiąże się z obniżeniem ryzyka rozwoju powikłań narządowych, w tym przerostu mięśnia lewej komory serca, przy czym kardioprotekcyjne działanie tego leku jest tylko częściowo związane z jego efektem hipotensyjnym. Przy tym samym stopniu redukcji BP u pacjentów przyjmujących walsartan obserwowano istotne zmniejszenie wskaźnika masy lewej komory w porównaniu z grupą pacjentów leczonych atenololem [23, 25].

Poza obniżaniem ryzyka rozwoju subklinicznych powikłań narządowych walsartan zmniejsza prawdopodobieństwo wystąpienia pełnoobjawowej HF. Ponadto, obok pozostałych ARB i inhibitorów ACE, należy do leków preferowanych u osób obciążonych metabolicznymi czynnikami ryzyka. Wieloośrodkowym badaniem VALUE (Valsartan Antihypertensive Long-term Use Evaluation) objęto ponad 15 tys. pacjentów z nadciśnieniem tętniczym i obciążonych wysokim ryzykiem sercowo-naczyniowym, których poddano randomizacji do grup otrzymujących amlodipinę lub walsartan. Średni czas obserwacji wynosił 4 lata. Mimo uzyskania większej redukcji BP w grupie przyjmującej amlodipinę częstość występowania pierwotnego, złożonego punktu końcowego (śmiertelności i chorobowości sercowej) nie różniła się istotnie między grupami. Natomiast walsartan skuteczniej od amlodipiny zapobiegał rozwojowi cukrzycy typu 2 [25].

\section{WALSARTAN — NIE TYLKO W NADCIŚNIENIU TĘTNICZYM}

Korzyści ze stosowania walsartanu udowodniono także w populacjach pacjentów po zawale serca, ze stabilną chorobą wieńcową, HF, cukrzycą typu 2 i stanami przedcukrzycowymi.

W dużych badaniach klinicznych wykazano, że nie tylko inhibitory ACE, lecz również wybrane ARB, w tym walsartan, poprawiają rokowanie pacjentów po zawale serca, szczególnie powikłanym HF. Do międzynarodowego, randomizowanego badania VALIANT (Valsartan in Acute Myocardial Infarction Trial) włączono blisko 15 tys. pacjentów ze świeżym zawałem serca powikłanym dysfunkcją lewej komory i/lub HF. Pacjenci zostali 
losowo przydzieleni do jednej z trzech grup terapeutycznych: przyjmującej walsartan, przyjmującej walsartan w skojarzeniu z kaptoprilem, otrzymującej kaptopril. Leczenie kontynuowano przez 25 miesięcy. Dowiedziono, że walsartan był równie skuteczny jak kaptopril w ograniczaniu śmiertelności z jakiejkolwiek przyczyny w tej grupie chorych [26]. Jednak tolerancja walsartanu była znacząco lepsza niż tolerancja kaptoprilu. Połączenie walsartanu z kaptoprilem nie przyniosło żadnych dodatkowych korzyści, a wręcz zwiększyło liczbę działań niepożądanych [26].

Badanie Val-HeFT (Valsartan Heart Failure Trial) było przeprowadzonym metodą podwójnie ślepej próby badaniem, w którym porównywano walsartan z placebo u ponad 5 tys. pacjentów z HF w II-IV klasie według New York Heart Association (NYHA). W grupie leczonej walsartanem obserwowano istotne obniżenie ryzyka wystąpienia pierwotnego punktu końcowego, który obejmował: śmiertelność z jakiejkolwiek przyczyny, nagłe zatrzymanie krążenia poddane skutecznej resuscytacji, hospitalizację z powodu HF oraz konieczność stosowania dożylnych leków inotropowych lub wazodylatacyjnych [27]. Leczenie walsartanem wiązało się także ze zmniejszeniem częstości występowania migotania przedsionków, wyższą frakcją wyrzutową lewej komory oraz niższymi stężeniami peptydów natriuretycznych $[28,29]$. Ponadto odnotowano korzystny wpływ walsartanu na jakość życia oraz na stopień nasilenia objawów podmiotowych i przedmiotowych $\mathrm{HF}, \mathrm{w}$ tym poprawę klasy według NYHA [30].

Do badania MARVAL (MicroAlbuminuria Reduction with VALsartan) włączono 332 pacjentów z cukrzycą typu 2 i mikroalbuminurią z zachowaną czynnością nerek, ze wspólistniejącym nadciśnieniem tętniczym lub bez niego. Chorych poddano randomizacji do grupy leczonej walsartanem lub amlodipiną przez 24 tygodnie. Walsartan zmniejszał wydalanie albumin w moczu skuteczniej od amlodipiny ( $42 \%$ v. 3\%) mimo podobnej redukcji BP w obu grupach [31].

Z kolei w badaniu NAVIGATOR (Nateglinide and Valsartan in Impaired Glucose Tolerance Outcomes Research) ponad 9 tys. pacjentów z upośledzoną tolerancją glukozy i chorobami układu krążenia lub obciążonych czynnikami ryzyka sercowo-naczyniowego objęto randomizacją do przyjmowania walsartanu lub placebo (oraz nateglinidu lub placebo). Po 5 latach obserwacji w grupie leczonej walsartanem obserwowano obniżenie ryzyka rozwoju cukrzycy w porównaniu z grupą otrzymującą placebo [32].
Natomiast przyjmowanie leku przeciwcukrzycowego nateglinidu — nie wpływało na ryzyko progresji upośledzonej tolerancji glukozy do cukrzycy.

\section{POŁACZENIA LEKOWE JAKO PODSTAWA LECZENIA HIPOTENSYJNEGO}

W kontekście najnowszych wytycznych ESC/ESH 2018i PTNT 2019, w których określono docelowe wartości BP na poniżej 130/80 mm Hg u większości pacjentów, terapia nadciśnienia tętniczego powinna się rozpoczynać od leku złożonego (SPC, single-pill combination) dwuskładnikowego. Zalecenie to jest pochodną niedostatecznej skuteczności monoterapii u większości pacjentów z nadciśnieniem tętniczym. Ponad $60 \%$ chorych wymaga co najmniej dwóch leków hipotensyjnych do osiągnięcia prawidłowej kontroli BP [33]. Do zalet SPC należy przede wszystkim uproszczenie schematu terapii, a przez to poprawa współpracy z pacjentem (lepszy compliance i niższe ryzyko pominięcia dawki leku hipotensyjnego), jak również szybsze osiągnięcie docelowych wartości BP w porównaniu z monoterapią oraz możliwość zastosowania mniejszych dawek poszczególnych składowych preparatu, a przez to obniżenie ryzyka wystąpienia działań niepożądanych (ryc. 1) [33-37]. Zgodnie z wytycznymi ESC/ESH 2018 i PTNT 2019 podstawowymi skojarzeniami dwóch leków, najlepiej w postaci SPC, są inhibitor ACE lub sartan w połączeniu $\mathrm{z}$ dihydropirydynowym antagonistą wapnia albo diuretykiem tiazydowym (lub tiazydopodobnym) [2,3].

\section{LECZENIE ZLOŻONE ZAWIERAJACE WALSARTAN}

Dołączenie leku o odmiennym mechanizmie działania nasila efekt hipotensyjny leku blokującego układ RAA, szczególnie u pacjentów, u których nadciśnienie tętnicze wiąże się z małą aktywnością reninową osocza, jak w przypadku wielu chorych w podeszłym wieku lub rasy czarnej. Jednocześnie łączne podanie dwóch leków w mniejszych dawkach obniża ryzyko wystąpienia objawów niepożądanych [2]. Do zalet stosowania walsartanu $\mathrm{w}$ skojarzeniu $\mathrm{z}$ antagonistą wapnia lub diuretykiem tiazydowym należą udokumentowany silny efekt hipotensyjny i duża rozpiętość dawek.

\section{Skojarzenie walsartanu z amlodipiną}

Amlodipina, dihydropirydynowy antagonista wapnia, jest lekiem o przedłużonym działaniu blokującym kanały wapniowe. Dobrze się wchłania z przewodu pokarmowego, osiągając maksymalne stężenie po 6- 


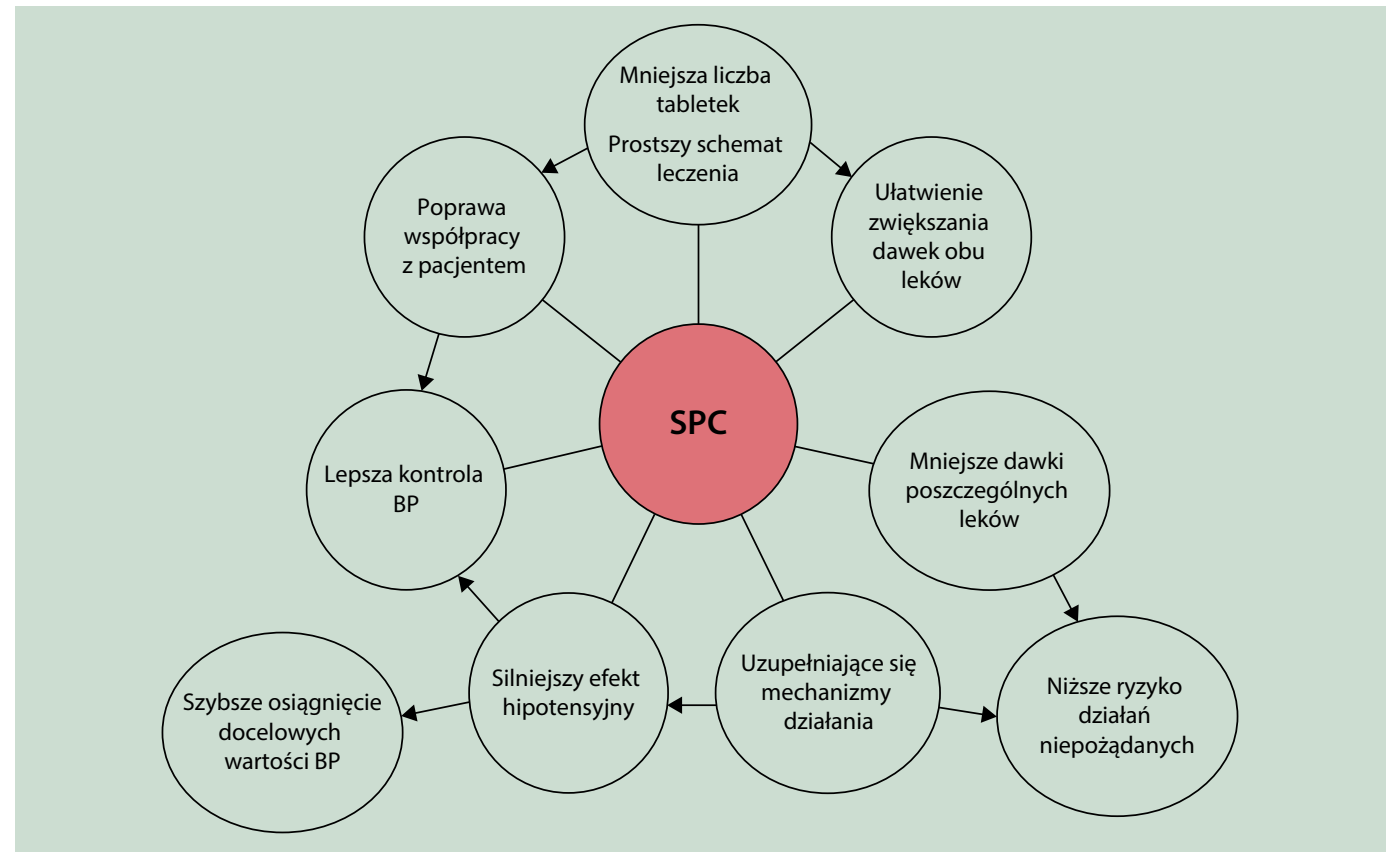

Rycina 1. Korzyści ze stosowania złożonych leków (SPC, single-pill combination) hipotensyjnych; BP (blood pressure) - ciśnienie tętnicze

-12 godzinach. Zapobiega to hipotonii w skojarzeniu $\mathrm{z}$ walsartanem, $\mathrm{w}$ przypadku którego maksymalne działanie następuje wcześniej [38]. Efekt hipotensyjny amlodipiny, podobnie jak walsartanu, utrzymuje się całą dobę. Mechanizm działania amlodipiny opiera się na hamowaniu napływu jonów wapniowych do komórek mięśni gładkich naczyń. Obniżenie BP wynika z bezpośredniego efektu wazodylatacyjnego i zmniejszenia oporu obwodowego [38-41]. Redukcja obciążenia następczego oraz poprawa przepływu wieńcowego pod wpływem amlodipiny sprawiają, że obok nadciśnienia tętniczego lek ten stosuje się także w chorobie niedokrwiennej serca. W badaniach doświadczalnych połączenie antagonisty wapnia z ARB, oprócz skutecznej kontroli BP, powodowało także zahamowanie przerostu lewej komory serca, poprawę funkcji śródbłonka i obniżenie stężenia cholesterolu frakcji lipoprotein o niskiej gęstości (LDL, low-density lipoprotein) [42].

Amlodipina ma szerokie wskazania w terapii nadciśnienia tętniczego. Jako dihydropirydynowy antagonista wapnia może być lekiem hipotensyjnym pierwszego wyboru u chorych $\mathrm{w}$ podeszłym wieku, z izolowanym skurczowym nadciśnieniem tętniczym, z miażdżycą tętnic kończyn dolnych, a także w przypadku towarzyszącej astmy oskrzelowej bądź przewlekłej obturacyjnej choroby płuc [2]. Ważną zaletą jest brak istotnego wpływu niewydolności nerek na farmakokinetykę leku. Ponadto jest bezpiecznym lekiem u pacjentów z HF i wykazuje neutralny profil metaboliczny. Dlatego połączenie amlodipiny z walsartanem może być leczeniem preferowanym w przypadku towarzyszących zaburzeń gospodarki węglowodanowej i/lub lipidowej [38-40]. Przykładowe subpopulacje pacjentów z nadciśnieniem tętniczym, u których skojarzenie walsartanu i amlodipiny może być leczeniem z wyboru, przedstawiono na rycinie 2 .

Skojarzenie walsartanu z amlodipiną wiąże się ze zmniejszeniem (nawet o 70\%) prawdopodobieństwa wystąpienia obrzęków obwodowych - stosunkowo częstych $\mathrm{w}$ przypadku stosowania amlodipiny w monoterapii [38, 43]. Jest to związane z odmiennym mechanizmem działania ARB i antagonistów wapnia: $w$ trakcie stosowania amlodipiny rozszerzeniu naczyń tętniczych nie towarzyszy rozszerzenie naczyń żylnych, co prowadzi do wzrostu ciśnienia hydrostatycznego w naczyniach włosowatych, przechodzenia płynu do przestrzeni zewnątrznaczyniowej i powstawania obrzęków. Dołączenie walsartanu do terapii amlodipiną powoduje rozszerzenie także naczyń żylnych, a w konsekwencji spadek ciśnienia hydrostatycznego i obniżenie ryzyka wystąpienia obrzęków (ryc. 3) [44]. Ma to istotne znaczenie kliniczne, ponieważ obrzęki obwodowe są wprawdzie łagodnymi, ale częstymi działaniami niepożądanymi terapii amlodipiną, prowadzącymi u 5\% chorych nawet do odstawienia leku [45]. 


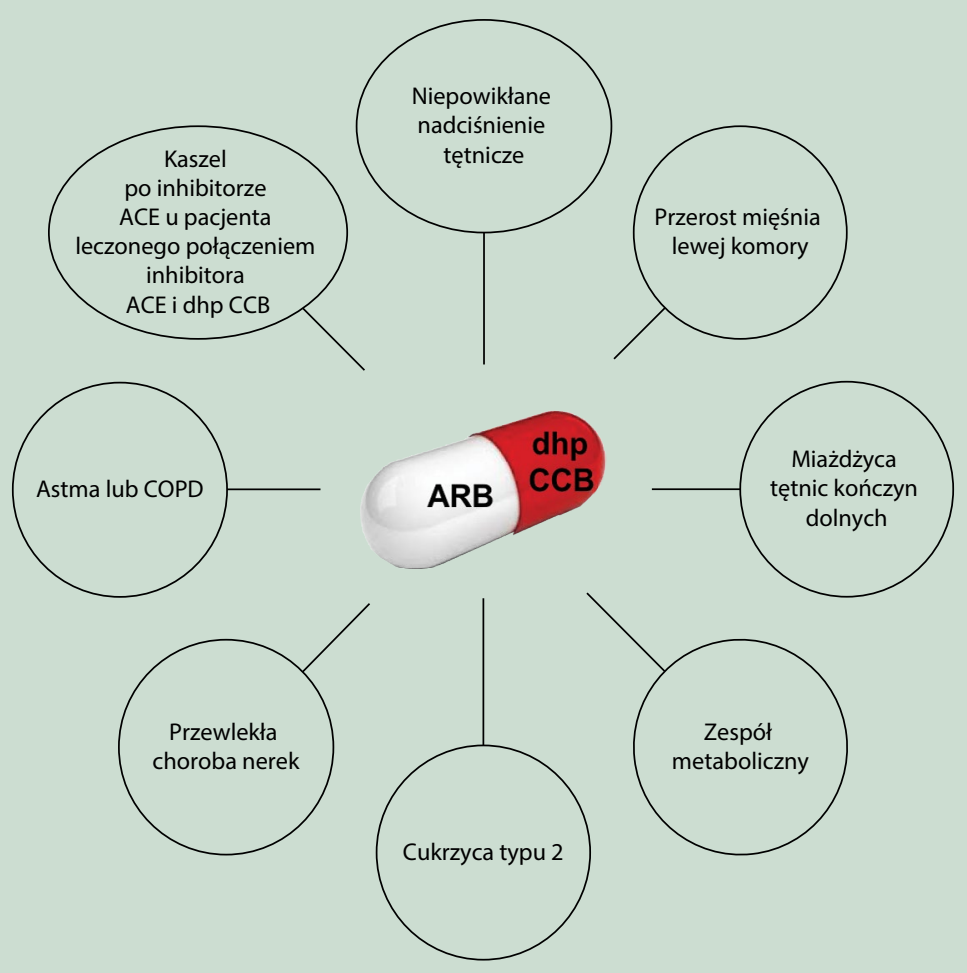

Rycina 2. Przykładowe subpopulacje pacjentów z nadciśnieniem tętniczym, u których skojarzenie sartanu i antagonisty wapnia (CCB, calcium channel blocker) może być leczeniem pierwszego rzutu (na podstawie wytycznych European Society of Cardiology/European Society of Hypertension [ESC/ESH] 2018 i Polskiego Towarzystwa Nadciśnienia Tętniczego [PTNT] 2019 [2, 3]); ACE (angiotensin-converting enzyme) - konwertaza angiotensyny; ARB (angiotensin receptor blocker) - antagonista receptora $\mathrm{AT}_{1}$ dla angiotensyny II; dhp (dihydropyridine) dihydropirydynowy; COPD (chronic obstructive pulmonary disease) - przewlekła obturacyjna choroba płuc

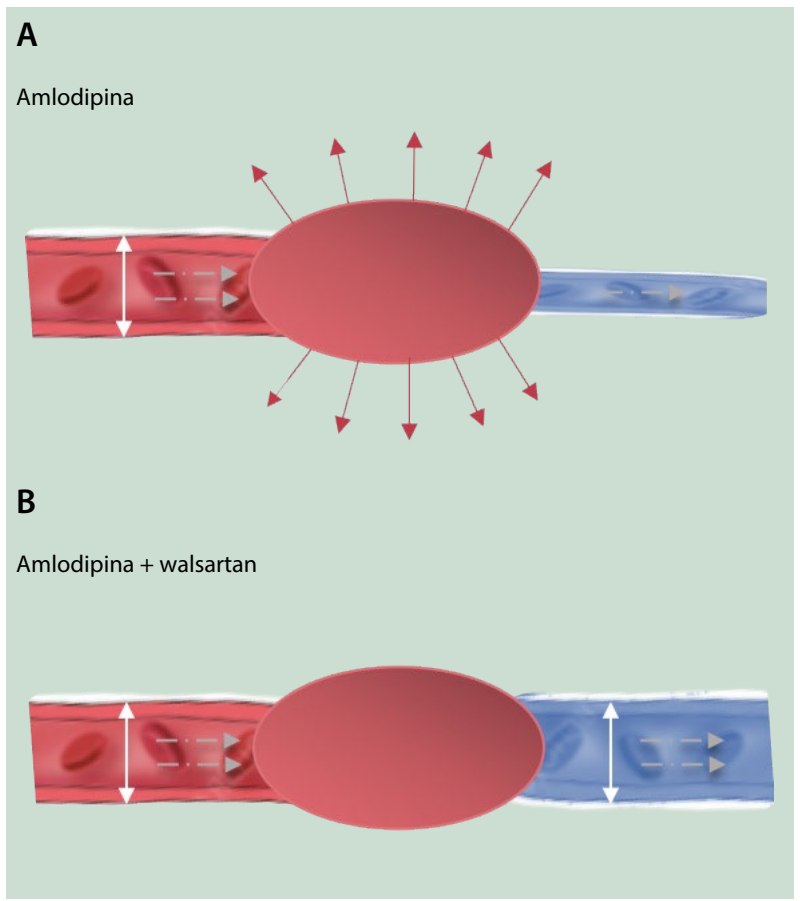

Rycina 3. Wpływ dołączenia walsartanu do terapii amlodipiną na ryzyko występowania obrzęków obwodowych (na podstawie [44]): A. Monoterapia amlodipiną - dochodzi do selektywnego rozszerzenia naczyń tętniczych, co powoduje przechodzenie płynu do przestrzeni zewnątrznaczyniowej i powstawanie obrzęków wskutek zwiększonego ciśnienia kapilarnego; B. Terapia złożona amlodipiną i walsartanem — dochodzi do rozszerzenia zarówno naczyń tętniczych, jak i żylnych, co powoduje obniżenie ciśnienia kapilarnego i zmniejszenie ryzyka wystąpienia obrzęków 
Wysoką skuteczność hipotensyjną leczenia skojarzonego walsartanem i amlodipina - nie tylko w porównaniu z monoterapią, ale także z leczeniem skojarzonym innymi preparatami - potwierdzono w badaniach klinicznych. Do badania EXPRESS-C zostali włączeni pacjenci z SBP 160-180 mm Hg, u których nie udało się uzyskać prawidłowych wartości BP po trwającym 5 tygodni leczeniu ramiprilem $\mathrm{w}$ skojarzeniu $\mathrm{z}$ felodipiną. Chorzy ci, przez kolejne 5 tygodni, byli poddani terapii walsartanem (w dawce $160 \mathrm{mg} / \mathrm{d}$.) w połączeniu z amlodipiną (10 mg/d.), co pozwoliło na normalizację BP (definiowaną jako SBP < $140 \mathrm{mmHg}$ ) u $64 \%$ chorych [46]. Z kolei badaniem EX-FAST objęto niemal 900 pacjentów z nadciśnieniem tętniczym, u których stosowana uprzednio monoterapia hipotensyjna okazała się nieskuteczna. Pacjentom podawano skojarzenie amlodipiny $\mathrm{z}$ walsartanem (w dawkach odpowiednio $5 \mathrm{mg} / 160 \mathrm{mg} / \mathrm{d}$. lub $10 \mathrm{mg} / 160 \mathrm{mg} / \mathrm{d}$.) przez 16 tygodni. Wykazano istotne obniżenie BP w obu grupach, niezależnie od preparatu, jaki pacjenci otrzymywali przed włączeniem do badania. Obniżenie BP poniżej wartości docelowych obserwowano u $73 \%$ chorych otrzymujących połączenie amlodipiny i walsartanu w dawce $5 / 160 \mathrm{mg} /$ dobęi $\mathrm{u} 75 \%$ w przypadku dawki 10/160 mg/dobę. Skuteczność hipotensyjna terapii nie zależała od stopnia nadciśnienia tętniczego, wieku, wskaźnika masy ciała czy wspólistnienia cukrzycy [47]. W innej analizie, obejmującej ponad 8 tys. pacjentów, oceniano skuteczność SPC amlodipina/walsartan przyjmowanego $1 \mathrm{raz} /$ dobę w różnych dawkach, tj. $5 / 80 \mathrm{mg}$, 5/160 mg lub 10/160 mg. Kontrolę BP (< 140/90 mm Hg) uzyskano u blisko $80 \%$ pacjentów. Podobnie jak w badaniu EX-FAST skuteczność terapii nie zależała od obecności chorób wspólistniejących ani od rodzaju stosowanego wcześniej leczenia hipotensyjnego ( $w$ terapii skojarzonej innymi preparatami) [48]. W badaniu EX-STAND wykazano szybsze i bardziej efektywne obniżenie BP pod wpływem terapii skojarzonej amlodipiną i walsartanem w porównaniu z monoterapią walsartanem u pacjentów rasy czarnej z wyjściowymi wartościami SBP między 160 a $200 \mathrm{~mm} \mathrm{Hg}$ [49].

\section{Skojarzenie walsartanu z hydrochlorotiazydem}

Hydrochlorotiazyd (HCTZ, hydrochlorothiazide) jest lekiem z grupy tiazydów o działaniu moczopędnym i obniżającym BP. Wpływając na hamowanie zwrotnego transportu jonów sodowych w kanalikach dystalnych krętych, zwiększa wydalanie sodu i wody. Sugeruje się, że działanie hipotensyjne jest związane nie tylko ze zmniejsze- niem objętości płynów pozakomórkowych, ale również z bezpośrednim działaniem na naczynia i zmniejszeniem oporu obwodowego. Spadek stężenia sodu w ścianach naczyń krwionośnych zmniejsza ich wrażliwość na endogenne aminy katecholowe. Początek działania HCTZ następuje 2 godziny po podaniu, a maksymalne działanie lek osiąga po 3-6 godzinach. Czas działania diuretycznego po podaniu pojedynczej dawki leku wynosi 6-12 godzin. Natomiast początek działania hipotensyjnego następuje po 3-4 dniach. Diuretyki tiazydowe są skuteczne u osób ze współczynnikiem przesączania kłębuszkowego (GFR, glomerular filtration rate) powyżej $30 \mathrm{ml} / \mathrm{min} / 1,73 \mathrm{~m}^{2}$, natomiast przy niższym GFR należy je zastąpić diuretykami pętlowymi [50-52]. Stosowanie HCTZ wiąże się z ryzykiem hipokaliemii oraz niekorzystnych działań metabolicznych. Dołączenie inhibitora ACE lub ARB do terapii HCTZ zmniejsza to ryzyko $[2,53,54]$.

W metaanalizie obejmującej randomizowane badania kontrolowane placebo, do której włączono ponad 4 tys. pacjentów, porównano skuteczność hipotensyjną walsartanu stosowanego $1 \mathrm{raz} /$ dobę w monoterapii z terapią skojarzoną walsartanem i HCTZ. Stopień obniżenia BP był wprost proporcjonalny do dawki walsartanu, natomiast skojarzenie z HCTZ pozwalało uzyskać docelowe wartości BP szybciej i u większego odsetka pacjentów: stosując dawkę 160 mg walsartanu, cel terapeutyczny osiągnięto u $48 \%$ pacjentów w przypadku monoterapii i u $75 \%$ w przypadku terapii skojarzonej z HCTZ; przy zastosowaniu dawki $320 \mathrm{mg}$ walsartanu - u $54 \% \mathrm{w}$ przypadku monoterapii i $\mathrm{u} 85 \% \mathrm{w}$ przypadku terapii skojarzonej [52]. Wynika z tego pośrednio, że w przypadku nieskuteczności walsartanu w dawce $160 \mathrm{mg} /$ dobę większe szanse na uzyskanie kontroli BP może dać dołączenie HCTZ (w stosunkowo niewielkiej dawce $12,5-25 \mathrm{mg}$ ) niż podwojenie dawki walsartanu (do dawki maksymalnej). Szczególnie wysoką skuteczność terapii skojarzonej z HCTZ w porównaniu z monoterapią obserwowano u pacjentów powyżej 65. roku życia i u osób otyłych [52].

W kolejnych badaniach potwierdzono, że terapia skojarzona walsartanem i HCTZ jest skuteczniejsza od monoterapii nie tylko walsartanem, ale także HCTZ [55-57].

Przegląd omówionych badań klinicznych z zastosowaniem walsartanu i jego skojarzeń z amlodipiną lub HCTZ przedstawiono w tabeli 1.

\section{PODSUMOWANIE}

Osiągnięcie niższych docelowych wartości BP, zgodnie z najnowszymi wytycznymi ESC/ESH i PTNT, 
Tabela 1. Przegląd najważniejszych badań klinicznych z zastosowaniem walsartanu i jego skojarzeń z amlodipiną lub hydrochlorotiazydem (HCTZ, hydrochlorothiazide)

\section{Badanie}

Populacja

Walsartan w monoterapii

VALUE [25]

Nadciśnienie tętnicze + wysokie ryzyko CV

VALIANT [26] Śsieży zawał serca

Val-HeFT [27] $\mathrm{HF}$

Cukrzyca + mikroalbuminuria

NAVIGATOR [32]

upośledzona tolerancja glukozy

+ wysokie ryzyko CV

Walsartan w skojarzeniu $\mathbf{z}$ amlodipiną

EXPRESS-C [46] Źle kontrolowane nadciśnienie tętnicze (nieskuteczna terapia ramiprilem + felodipiną)

EX-FAST [47]

Źle kontrolowane nadciśnienie tętnicze (nieskuteczna monoterapia nadciśnienia tętniczego)

\section{Walsartan w skojarzeniu z HCTZ}

Calhoun i wsp. [55] Ciężkie nieleczone nadciśnienie tętnicze

VALOR [56]

Nadciśnienie tętnicze 2. i 3. stopnia

Val-DICTATE [57] Źle kontrolowane nadciśnienie tętnicze (nieskuteczna monoterapia HCTZ)

\section{Leczenie}

walsartan $v$. amlodipina

walsartan $v$. kaptopril v. walsartan + kaptopril

walsartan $v$. placebo

walsartan $v$. amlodipina

walsartan $v$. placebo

walsartan + amlodipina

walsartan $+\mathrm{HCTZ}$ v. walsartan

walsartan + HCTZ

v. walsartan

walsartan + HCTZ v. podwojona dawka HCTZ

\section{Najważniejsze wyniki}

W grupie leczonej amlodipiną:

- większa redukcja BP

- niższe ryzyko zawału serca

W grupie leczonej walsartanem:

- niższe ryzyko rozwoju cukrzycy typu 2

- bez różnic w zakresie częstości pierwotnego punktu końcowego (chorobowości i śmiertelności sercowej) między grupami

Bez różnic pod względem śmiertelności ogólnej i ryzyka zdarzeń CV między grupami

Lepsza tolerancja leczenia w grupie przyjmującej walsartan

W grupie leczonej walsartanem:

- obniżenie ryzyka złożonego punktu końcowego (śmiertelność ogólna, nagle zatrzymanie krążenia poddane skutecznej resuscytacji, hospitalizacja z powodu HF, konieczność stosowania dożylnych leków inotropowych lub wazodylatacyjnych)

- obniżenie ryzyka hospitalizacji z powodu HF

- zmniejszenie częstości występowania migotania przedsionków

- wyższa frakcja wyrzutowa

- niższe stężenia peptydów natriuretycznych

- poprawa klasy wg NYHA

W grupie leczonej walsartanem - zmniejszenie wydalania albumin z moczem

W grupie leczonej walsartanem - obniżenie ryzyka rozwoju cukrzycy typu 2

Osiągnięcie docelowych wartości BP u $64 \%$ pacjentów

Osiągnięcie docelowych wartości BP u 3/4 pacjentów

Częściej osiagane docelowe wartości BP w przypadku terapii skojarzonej (48\%) niż w przypadku monoterapii walsartanem (27\%) po 6 tygodniach

Większa redukcja BP w przypadku terapii skojarzonej

Częściej osiągane docelowe wartości BP w przypadku terapii skojarzonej (37\%) niż w przypadku monoterapii HCTZ (16\%) po 4 tygodniach

CV (cardiovascular) - sercowo-naczyniowe; BP (blood pressure) - ciśnienie tętnicze; HF (heart failure) — niewydolność serca; NYHA — New York Heart Association 
u większości chorych wymaga zastosowania terapii skojarzonej - najlepiej w postaci połączeń lekowych SPC — już na początku leczenia. Leczenie walsartanem w skojarzeniu zarówno z amlodipiną, jak i HCTZ ma udokumentowany silny efekt hipotensyjny. Jednocześnie dołączenie walsartanu do terapii amlodipiną lub HCTZ wiąże się z obniżeniem ryzyka działań niepożądanych (takich jak obrzęki obwodowe w przypadku monoterapii amlodipiną czy hipokaliemia w przypadku monoterapii HCTZ). Biorąc pod uwagę całodobowe działanie hipotensyjne obu składowych, korzystny profil metaboliczny i obniżenie ryzyka rozwoju powikłań narządowych, udowodnione w odniesieniu do obu składowych, szczególnie użyteczne do stosowania w szerokiej populacji pacjentów z nadciśnieniem tętniczym może być połączenie walsartanu i amlodipiny. Oprócz osób z niepowikłanym nadciśnieniem tętniczym, to skojarzenie może być terapią pierwszego wyboru u pacjentów z nadciśnieniem tętniczym i współistniejącym przerostem mięśnia lewej komory, miażdżycą tętnic kończyn dolnych, zaburzeniami metabolicznymi (cukrzycą typu 2, zespołem metabolicznym) czy przewlekłą chorobą nerek, a także wtedy, gdy stosowanie niektórych innych leków hipotensyjnych jest przeciwwskazane (np. w przypadku astmy lub kaszlu po inhibitorach ACE).

\section{KONFLIKT INTERESÓW}

Agnieszka Kapłon-Cieślicka: honoraria za wykłady, granty wyjazdowe lub udział w badaniach klinicznych: Abbott Laboratories, Bayer, Boehringer Ingelheim, Boston Scientific, Krka, MSD, Pfizer, Sandoz, Servier, Viventum.

Agata Tymińska: honoraria za wykłady lub udział w badaniach klinicznych: Novartis, Boehringer Ingelheim.

\section{PIŚMIENNICTWO}

1. World Health Organization. www.who.int/topics/cardiovascular_diseases/en/ (2.09.2019).

2. Tykarski A, Filipiak KJ, Januszewicz A, et al. Zasady postępowania w nadciśnieniu tętniczym - 2019 rok. Nadciśnienie Tętnicze w Praktyce. 2019; 5(1): 1-86.

3. Williams B, Mancia G, Spiering W, et al. Authors/Task Force Members, ESC Scientific Document Group. 2018 ESC/ESH guidelines for the management of arterial hypertension. Eur Heart J. 2018; 39(33): $3021-$ -3104, doi: 10.1093/eurheartj/ehy339, indexed in Pubmed: 30165516.

4. Zdrojewski $Ł$, Zdrojewski T, Rutkowski M, et al. Prevalence and control of cardiovascular risk factors in Poland. Assumptions and objectives of the NATPOL 2011 survey. Kardiol Pol. 2013; 71(4): 381-392, doi: 10.5603/KP.2013.0066, indexed in Pubmed: 23788344.

5. Niklas A, Flotyńska A, Puch-Walczak A, et al. WOBASZ II Investigators. Prevalence, awareness, treatment and control of hypertension in the adult Polish population - multi-center National Population Health Examination Surveys — WOBASZ studies. Arch Med Sci.
2018; 14(5): 951-961, doi: 10.5114/aoms.2017.72423, indexed in Pubmed: 30154875

6. Lv J, Ehteshami P, Sarnak MJ, et al. Effects of intensive blood pressure lowering on the progression of chronic kidney disease: a systematic review and meta-analysis. CMAJ. 2013; 185(11): 949-957, doi: 10.1503/cmaj.121468, indexed in Pubmed: 23798459.

7. Tymińska A, Kapłon-Cieślicka A. Wiek naczyń - u kogo i jak go oceniać? Czy możemy „odmłodzić” naczynia naszych pacjentów? Choroby Serca i Naczyń. 2019; 16(2): 118-129, doi: 10.5603/ /ChSiN.2019.0019.

8. Piepoli MF, Hoes AW, Agewall S, et al. Authors/Task Force Members, Additional Contributor: Simone Binno (Italy), Document Reviewers, ESC Scientific Document Group. 2016 European guidelines on cardiovascular disease prevention in clinical practice: the Sixth Joint Task Force of the European Society of Cardiology and Other Societies on Cardiovascular Disease Prevention in Clinical Practice (constituted by representatives of 10 societies and by invited experts). Developed with the special contribution of the European Association for Cardiovascular Prevention \& Rehabilitation (EACPR). Eur Heart J. 2016; 37(29): 2315-2381, doi: 10.1093/eurheartj/ehw106, indexed in Pubmed: 27222591.

9. Whelton PK, Carey RM, Aronow WS, et al. 2017 ACC/AHA/AAPA/ABC/ /ACPM/AGS/APhA/ASH/ASPC/NMA/PCNA guideline for the prevention, detection, evaluation, and management of high blood pressure in adults: a report of the American College of Cardiology/American Heart Association Task Force on Clinical Practice Guidelines. Hypertension. 2018; 71(6): e13-e115, doi: 10.1161/HYP.0000000000000065.

10. Wright JT, Williamson JD, Whelton PK, et al. SPRINT Research Group. A randomized trial of intensive versus standard blood-pressure control. N Engl J Med. 2015; 373(22): 2103-2116, doi: 10.1056/NEJMoa1511939, indexed in Pubmed: 26551272.

11. Oparil S, Silfani TN, Walker JF. Role of angiotensin receptor blockers as monotherapy in reaching blood pressure goals. Am J Hypertens. 2005; 18(2 Pt 1): 287-294, doi: 10.1016/j.amjhyper.2004.07.021, indexed in Pubmed: 15752958.

12. Fogari R, De Gasparo M. Addressing those two that go together: the angiotensin II receptors and their role in blood-flow regulation. Blood Press. 2001; 10(1): 6-15, indexed in Pubmed: 11332335.

13. Markham A, Goa KL. Valsartan. A review of its pharmacology and therapeutic use in essential hypertension. Drugs. 1997; 54(2): 299-311, doi: 10.2165/00003495-199754020-00009, indexed in Pubmed: 9257084.

14. Opolski G, Filipiak KJ. Leki hamujące układ renina-angiotensyna-aldosteron. Urban \& Partner, Wrocław 2000.

15. Neutel JM. Ambulatory blood pressure monitoring to assess the comparative efficacy and duration of action of a novel new angiotensin II receptor blocker — telmisartan. Blood Press Suppl. 2001; 1: 27-32, indexed in Pubmed: 11333011.

16. Gleiter $\mathrm{CH}$, Jägle $\mathrm{C}$, Gresser U, et al. Candesartan. Cardiovasc Drug Rev. 2004; 22(4): 263-284, indexed in Pubmed: 15592574.

17. Lacourcière $Y$, Krzesinski JM, White WB, et al. Sustained antihypertensive activity of telmisartan compared with valsartan. Blood Press Monit. 2004; 9(4): 203-210, indexed in Pubmed: 15311147

18. White WB, Lacourciere Y, Davidai G. Effects of the angiotensin II receptor blockers telmisartan versus valsartan on the circadian variation of blood pressure: impact on the early morning period. Am J Hypertens. 2004; 17(4): 347-353, doi: 10.1016/j. amjhyper.2004.02.016, indexed in Pubmed: 15062889.

19. Ponikowski P, Voors AA, Anker SD SD, et al. ESC Scientific Document Group. 2016 ESC guidelines for the diagnosis and treatment of acute and chronic heart failure: the Task Force for the diagnosis and treatment of acute and chronic heart failure of the European Society of Cardiology (ESC). Developed with the special contribution of the Heart Failure Association (HFA) of the ESC. Eur Heart J. 2016; 37(27): 2129-2200, doi: 10.1093/eurheartj/ehw128, indexed in Pubmed: 27206819. 
20. Pool JL, Glazer R, Chiang YT, et al. Dose-response efficacy of valsartan, a new angiotensin II receptor blocker. J Hum Hypertens. 1999; 13(4): 275-281, indexed in Pubmed: 10333347.

21. Hermida RC, Calvo C, Ayala DE, et al. Administration time-dependent effects of valsartan on ambulatory blood pressure in hypertensive subjects. Hypertension. 2003; 42(3): 283-290, doi: 10.1161/01. HYP.0000084855.32823.DA, indexed in Pubmed: 12874091

22. Hermida RC, Calvo C, Ayala DE, et al. Treatment of non-dipper hypertension with bedtime administration of valsartan. J Hypertens. 2005; 23(10): 1913-1922, doi: 10.1097/01.hjh.0000182522.21569. c5, indexed in Pubmed: 16148616.

23. Thürmann PA, Thürmann PA. Angiotensin II antagonism and the heart: valsartan in left ventricular hypertrophy. J Cardiovasc Pharmacol. 1999; 33(Suppl 1): S33-S36; discussion S41-S43, indexed in Pubmed: 10028952.

24. Thürmann PA. Regression of left ventricular hypertrophy following angiotensin II receptor blockade: valsartan on left ventricular hypertrophy. Cardiovasc Rev Rep. 2000; 21: 70-73

25. Kjeldsen SE, Julius S, Mancia G, et al. VALUE Trial Investigators Effects of valsartan compared to amlodipine on preventing type 2 diabetes in high-risk hypertensive patients: the VALUE trial. J Hypertens. 2006; 24(7): 1405-1412, doi: 10.1097/01.hjh.0000234122.55895.5b, indexed in Pubmed: 16794491

26. Pfeffer MA, McMurray J, Velazquez EJ. Valsartan, captopril, or both in myocardial infarction complicated by heart failure, left ventricular dysfunction, or both. N Engl J Med. 2003; 349(20): 1893-1906, doi: 10.1056/NEJMoa032292, indexed in Pubmed: 14610160.

27. Cohn JN, Tognoni G. Valsartan Heart Failure Trial Investigators. A randomized trial of the angiotensin-receptor blocker valsartan in chronic heart failure. N Engl J Med. 2001; 345(23): 1667-1675, doi: 10.1056/ /NEJMoa010713, indexed in Pubmed: 11759645.

28. Maggioni AP, Latini R, Carson PE, et al. Val-HeFT Investigators. Valsartan reduces the incidence of atrial fibrillation in patients with heart failure: results from the Valsartan Heart Failure Trial (Val-HeFT). Am Heart J. 2005; 149(3): 548-557, doi: 10.1016/j.ahj.2004.09.033, indexed in Pubmed: 15864246.

29. Baruch L, Glazer RD, Aknay N, et al. Morbidity, mortality, physiologic and functional parameters in elderly and non-elderly patients in the Valsartan Heart Failure Trial (Val-HeFT). Am Heart J. 2004; 148(6): $951-$ -957, doi: 10.1016/j.ahj.2004.06.001, indexed in Pubmed: 15632877.

30. Majani G, Giardini A, Opasich C, et al. Effect of valsartan on quality of life when added to usual therapy for heart failure: results from the Valsartan Heart Failure Trial. J Card Fail. 2005; 11(4): 253-259, indexed in Pubmed: 15880333

31. Viberti G, Wheeldon NM. MicroAlbuminuria Reduction With VALsartan (MARVAL) Study Investigators. Microalbuminuria reduction with valsartan in patients with type 2 diabetes mellitus: a blood pressure-independent effect. Circulation. 2002; 106(6): 672-678, doi: 10.1161/01. cir.0000024416.33113.0a, indexed in Pubmed: 12163426.

32. McMurray JJ, Holman RR, Haffner SM, et al. NAVIGATOR Study Group. Effect of valsartan on the incidence of diabetes and cardiovascular events. N Engl J Med. 2010; 362(16): 1477-1490, doi: 10.1056/NEJMoa1001121, indexed in Pubmed: 20228403

33. Hansson L, Zanchetti A, Carruthers SG, et al. Effects of intensive blood-pressure lowering and low-dose aspirin in patients with hypertension: principal results of the Hypertension Optimal Treatment (HOT) randomised trial. HOT Study Group. Lancet. 1998; 351(9118): 1755-1762, doi: 10.1016/s0140-6736(98)04311-6, indexed in Pubmed: 9635947

34. Mochizuki S, Dahlöf B, Shimizu M, et al. Jikei Heart Study group Valsartan in a Japanese population with hypertension and other cardiovascular disease (Jikei Heart Study): a randomised, open-label, blinded endpoint morbidity-mortality study. Lancet. 2007; 369(9571): 1431-1439, doi: 10.1016/S0140-6736(07)60669-2, indexed in Pubmed: 17467513 .
35. Bakris GL. Maximizing cardiorenal benefit in the management of hypertension: achieve blood pressure goals. J Clin Hypertens (Greenwich). 1999; 1(2): 141-147, indexed in Pubmed: 11416606.

36. Neutel JM. Prescribing patterns in hypertension: the emerging role of fixed-dose combinations for attaining BP goals in hypertensive patients. Curr Med Res Opin. 2008; 24(8): 2389-2401, doi: 10.1185/03007990802262457, indexed in Pubmed: 18616863.

37. Calhoun DA. Use of single-pill combination therapy in the evolving paradigm of hypertension management. Expert Opin Pharmacother. 2009; 10(12): 1869-1874, doi: 10.1517/14656560902980210, indexed in Pubmed: 19496740.

38. Philipp T, Smith TR, Glazer R, et al. Two multicenter, 8-week, randomized, double-blind, placebo-controlled, parallel-group studies evaluating the efficacy and tolerability of amlodipine and valsartan in combination and as monotherapy in adult patients with mild to moderate essential hypertension. Clin Ther. 2007; 29(4): 563-580, doi: 10.1016/j. clinthera.2007.03.018, indexed in Pubmed: 17617280.

39. Barylski M. Dwanaście powodów, dla których warto stosować amlodipine. Med Fakt. 2014; $7:$ 41-47.

40. Kurtz A. Do calcium-activated chloride channels control renin secretion? News Physiol Sci. 1990; 5(2): 43-46, doi: 10.1152/physiologyonline.1990.5.2.43.

41. Haria M, Wagstaff AJ. Amlodipine. A reappraisal of its pharmacological properties and therapeutic use in cardiovascular disease. Drugs. 1995; 50(3): 560-586, doi: 10.2165/00003495-199550030-00009, indexed in Pubmed: 8521773

42. Takayama M, Arakawa E, Yao K, et al. Effects of combination of angiotensin receptor blocker and calcium channel blocker on ox-LDL levels and cardiovascular dysfunction in Dahl rats. Pharmacology. 2006; 77(4): 179-187, doi: 10.1159/000094656, indexed in Pubmed: 16864986.

43. Fogari R, Zoppi A, Derosa G, et al. Effect of valsartan addition to amlodipine on ankle oedema and subcutaneous tissue pressure in hypertensive patients. J Hum Hypertens. 2007; 21(3): 220-224, doi: 10.1038/sj.jhh.1002140, indexed in Pubmed: 17215848

44. Epstein BJ, Vogel K, Palmer BF. Dihydropyridine calcium channel antagonists in the management of hypertension. Drugs. 2007; 67(9): 1309-1327, doi: 10.2165/00003495-200767090-00005, indexed in Pubmed: 17547473

45. Makani H, Bangalore S, Romero J, et al. Peripheral edema associated with calcium channel blockers: incidence and withdrawal rate - a meta-analysis of randomized trials. J Hypertens. 2011; 29(7): 1270-1280, doi: 10.1097/HJH.0b013e3283472643, indexed in Pubmed: 21558959.

46. Trenkwalder P, Schaetzl R, Borbas E, et al. Efficacy and safety of the combination of amlodipine 10/valsartan 160 in hypertensive patients not controlled by the combination of ramipril 5/felodipine 5. The EXPRESS-C trial. J Hypertens. 2007; 25(Suppl 2): S228 (abstract P24.261).

47. Allemann $\mathrm{Y}$, Fraile $\mathrm{B}$, Lambert $\mathrm{M}$, et al. Efficacy of the combination of amlodipine and valsartan in patients with hypertension uncontrolled with previous monotherapy: the Exforge in Failure after Single Therapy (EX-FAST) study. J Clin Hypertens (Greenwich). 2008; 10(3): 185-194, indexed in Pubmed: 18326958.

48. Karpov Y, Dongre N, Vigdorchik A, et al. Amlodipine/valsartan single-pill combination: a prospective, observational evaluation of the real-life safety and effectiveness in the routine treatment of hypertension. Adv Ther. 2012; 29(2): 134-147, doi: 10.1007/s12325-011-0095-0, indexed in Pubmed: 22271158.

49. Flack JM, Calhoun DA, Satlin L, et al. Efficacy and safety of initial combination therapy with amlodipine/valsartan compared with amlodipine monotherapy in black patients with stage 2 hypertension: the EX-STAND study. J Hum Hypertens. 2009; 23(7): 479-489, doi: 10.1038/jhh.2008.153, indexed in Pubmed: 19190658.

50. Kaplan NM. The choice of thiazide diuretics: why chlorthalidone may replace hydrochlorothiazide. Hypertension. 2009; 54(5): 951-953, 
doi: 10.1161/HYPERTENSIONAHA.109.135061, indexed in Pubmed: 19752290.

51. van Brummelen P, Man in't Veld AJ, Schalekamp MA. Hemodynamic changes during long-term thiazide treatment of essential hypertension in responders and nonresponders. Clin Pharmacol Ther. 1980; 27(3): 328-336, doi: 10.1038/clpt.1980.44, indexed in Pubmed: 6987024.

52. Weir MR, Levy D, Crikelair N, et al. Time to achieve blood-pressure goal: influence of dose of valsartan monotherapy and valsartan and hydrochlorothiazide combination therapy. Am J Hypertens. 2007; 20(7): 807-815, doi: 10.1016/j.amjhyper.2007.02.017, indexed in Pubmed: 17586417.

53. Pool JL, Glazer R, Weinberger M, et al. Comparison of valsartan/ /hydrochlorothiazide combination therapy at doses up to $320 / 25 \mathrm{mg}$ versus monotherapy: a double-blind, placebo-controlled study followed by long-term combination therapy in hypertensive adults. Clin Ther. 2007; 29(1): 61-73, doi: 10.1016/j.clinthera.2007.01.007, indexed in Pubmed: 17379047
54. Nash DT, McNamara MS. Valsartan combination therapy in the management of hypertension - patient perspectives and clinical utility. Integr Blood Press Control. 2009; 2: 39-54, indexed in Pubmed: 21949614.

55. Calhoun DA, Glazer RD, Pettyjohn FS, et al. Efficacy and tolerability of combination therapy with valsartan/hydrochlorothiazide in the initial treatment of severe hypertension. Curr Med Res Opin. 2008; 24(8): 2303-2311, doi: 10.1185/03007990802271946, indexed in Pubmed: 18593517.

56. Lacourciere Y, Hebert D, Assouline L, et al. Effective blood-pressure control with valsartan/HCTZ combination therapy in patients with moderate to severe systolic hypertension: the VALOR trial. Am J Hypertens. 2004; 17(5): S115 (abstract P-225)

57. White WB, Calhoun DA, Samuel R, et al. Improving blood pressure control: increase the dose of diuretic or switch to a fixed-dose angiotensin receptor blocker/diuretic? The Valsartan Hydrochlorothiazide Diuretic for Initial Control and Titration to Achieve Optimal Therapeutic Effect (Val-DICTATE) trial. J Clin Hypertens (Greenwich). 2008; 10(6): 450-458, indexed in Pubmed: 18550935. 